\title{
The Effect of Active Smoking of Pregnant Women on Premature Birth: A Meta Analysis
}

\author{
Imam Setya Arifian'), Vitri Widyaningsih²), Hanung Prasetya3) \\ 1)Masters Program in Public Health, Universitas Sebelas Maret \\ 2)Faculty of Medicine, Universitas Sebelas Maret \\ 3)Study Program in Acupuncture, Health Polytechnics, Ministry of Health Surakarta
}

\section{ABSTRACT}

Background: Smoking is a well-known major risk factor for premature death from cancer, cardiovascular disease, and chronic obstructive pulmonary disease. When a pregnant woman smokes, she puts herself and her baby at risk. This is because the developing fetus / baby in the mother's womb is in contact with the mother's bloodstream. Any chemical that the mother inhales or swallows can affect the fetus. This study aims to analyze the magnitude of the effect of active smoking on pregnant women with preterm labor by means of a meta-analysis study.

Subjects and Method: This was a systematic review and meta-analysis carried out by following the PRISMA flow diagram. The process of searching for articles is through a journal database which includes: PubMed, Springer Link, and Google Scholar by selecting articles published in 2005-2020. Keywords used include: "Maternal Smoking" OR "Smoking During Pregnancy" AND "Preterm Birth" OR "Premature" AND "multivariate" AND "AOR". The inclusion criteria were full paper articles with observational study design, articles in English, and multivariate analysis used with adjusted odds ratios. Articles that meet the requirements are analyzed using the Revmen 5.3 application.

Results: A total of 19 articles were reviewed in this study with a cross-sectional cohordant study design. A meta-analysis of 6 cohort studies showed that active smoking in pregnant women had a 1.34-fold increase in the incidence of preterm birth compared with nonsmoking pregnant women $(\mathrm{aOR}=1.34 ; 95 \% \mathrm{CI}=0.14$ to $5.80 ; \mathrm{p}=$ 0.002). A meta-analysis of 5 cross-sectional studies showed that active smoking in pregnant women had a 1.29-fold increase in the incidence of preterm birth compared with nonsmoking pregnant women $(\mathrm{aOR}=1.29 ; 95 \% \mathrm{CI}=0.89$ to $4.54 ; \mathrm{p}=0.04)$.

Conclusion: Active smoking in pregnant women increases preterm labor.

Keywords: pregnant women smoking, premature labor, meta-analysis

\section{Correspondence:}

Imam Setya Arifian. Masters Program in Public Health, Universitas Sebelas Maret. Jl. Ir. Sutami 36A, Surakarta 57126, Central Java. Email: Imamsetyaarifian@gmail.com. Mobile: o85253402793.

Cite this as:

Arifian IS, Widyaningsih V, Prasetya H (2021). The Effect of Active Smoking of Pregnant Women on Premature Birth: A Meta Analysis. J Matern Child Health. 06(01): 95-107. https://doi.org/10.26911/thejmch.2021.06.01.10.

(c) (F) (-) Journal of Maternal and Child Health is licensed under a Creative Commons

Attribution-NonCommercial-ShareAlike 4.0 International License.

\section{BACKGROUND}

Smoking is a well-known major risk factor for premature death from cancer, cardiovascular disease, and chronic obstructive pulmonary disease (Arcavi, 2004). More than 7,00o chemicals are found in smoked tobacco, including through a pipe, and including at least 250 chemicals that can cause cancer and are known to be toxic. Globally, more than 22,00o people die from tobacco use or are exposed to secondhand smoke every day - one person every 4 seconds every day. Tobacco use affects almost all organs of the human body 
(Giemza, 2004). The results of Arfailasufandi's study (2019) show a positive relationship between exposure to cigarette smoke and the incidence of cervical cancer and it is statistically significant. Women who were exposed to secondhand smoke were 12.57 times more likely to develop cervical cancer.

When a pregnant woman smokes, she puts herself and her baby at risk. Because the fetus, the developing baby in the mother's womb (womb), comes into contact with the mother's bloodstream, any chemicals that the mother inhales or swallows can affect the fetus (Delmas, 2005). Based on Indonesia's Health SDG Profile data, the prevalence of women who smoke in Indonesia is $4.5 \%$ (WHO, 2019). Data from Indonesian tobacco factsheet of women exposed to cigarette smoke at home is $52.7 \%$ (WHO, 2018).

WHO defines preterm birth as all births before the full 37 weeks of gestation, or less than 259 days from the first date of a woman's last menstrual period (WHO, 1977). Complications of preterm birth were the leading cause of death in children under 5 years globally in 2016, accounting for about $16 \%$ of all deaths, and $35 \%$ of deaths among newborns (UNICEF et al., 2017).

Listiani's study (2018) concluded that one of the determinants of neonatal mortality is prematurity, among other factors, asphyxia, low birth weight, and infection. In Susanti's study (2020) states that exposure to cigarette smoke can cause LBW. In addition, Sudaryanto's research (2019) states that smoking is a risk factor for hypertension in women.

In a study conducted by Azagba et al., (2020) found that the prevalence of smoking during pregnancy was $6.89 \%$ in 2017 in the United States. This study states that there are still quite a number of pregnant women who smoke during pregnancy.
Guo et al. (2019) showed that high concentrations of air pollution significantly influence the risk of adverse birth outcomes. However, further studies need to be done to focus more on smoking habits during pregnancy on risk factors for preterm birth.

Based on the above background, the researcher chose to use meta-analysis to expand the application of evidence from the results of previous primary studies, and was able to obtain the strongest empirical causality evidence on the relationship between variables, with a larger sample. Researchers want to conduct a meta-analysis study related to pregnant women who smoke actively against preterm birth. This topic is very important in view of the number of women who smoke which allows preterm birth. Therefore, a meta-analysis study is important in order to summarize and combine relevant studies on the influence of pregnant women who smoke on the incidence of preterm birth so that the results of the analysis can provide a summary based on evidence.

\section{SUBJECTS AND METHOD}

\section{Study Design}

This was a systematic review and meta-analysis carried out by following the PRISMA flow diagram. The process of searching for articles is carried out through a journal database which includes: PubMed, Springer Link, Google Scholar and Science Direct. The keywords used are: "Maternal Smoking" OR "Smoking During Pregnancy" AND "Preterm Birth" OR "Premature" AND "multivariate" AND "AOR"

\section{Inclusion Criteria}

The inclusion criteria for articles that can be reviewed are full paper articles with observational study design, articles in English, multivariate analysis used with adjusted odds ratios, the intervention given is 
Arifian et al./ The Effect of Active Smoking of Pregnant Women on Premature Birth

active smoking during pregnancy, study subjects are pregnant women, the outcome is preterm birth.

\section{Exclusion Criteria}

Exclusion criteria for articles included primary articles published where meta-analysis was carried out and statistical results reported in the form of a bivariate analysis.

\section{Variable Operational Definition}

The article search was carried out by considering the eligibility criteria defined using the PICO model. The population in the study was pregnant women with intervention in the form of active smoking, comparison with no smoking and outcomes in the form of preterm birth.

Premature is labor that occurs at 20 to 36 weeks of gestation, can be calculated from the first day of the last menstruation.

Smoking behavior is an act of burning cigarettes and then inhaling cigarette smoke using a pipe or cigarette and blowing it out so that it can cause smoke.

\section{Instrument}

The research stages followed the PRISMA flow diagram and the assessment of the quality of research articles using the Critical Appraisal Skills Program (CASP) for Cohort Study, Critical Appraisal Checklist for Cross-sectional Study (CEBMa, 2014).

\section{Data Analysis}

The data analysis process in this study was carried out using the Review Manager application (RevMen 5.3) to determine the effect size and heterogeneity of the study. The results of meta-analysis data processing are presented in the form of a forest plot and a funnel plot.

\section{RESULTS}

The process of searching for articles is carried out by PRISMA. The flow diagram can be seen in Figure 1.

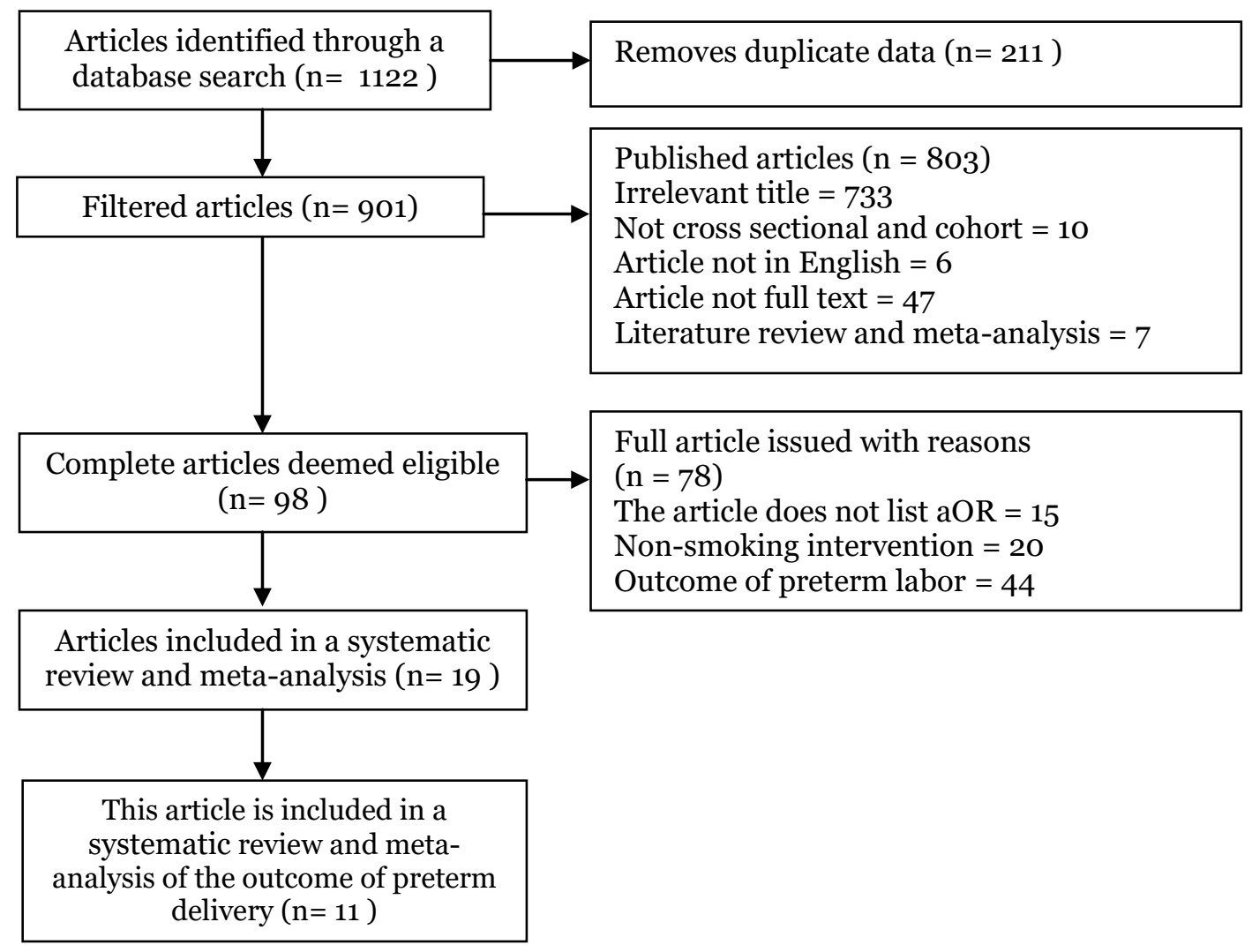

Figure 1. PRISMA flow diagram 
Arifian et al./ The Effect of Active Smoking of Pregnant Women on Premature Birth

Primary studies related to the effect of active smoking on pregnant women on preterm labor consisted of 5 studies from the Asian continent, 2 studies from the continent of Europe, and 4 studies from the continent of North America. Figure 2 shows the areas where articles were drawn according to the inclusion criteria. Next, the researcher conducted an assessment of the quality of the articles (Tables 1 and 2). Table 3 shows that there are 6 cohort study articles and 5 cross-sectional study articles as evidence of the association of the effect of active smoking in pregnant women on preterm birth.

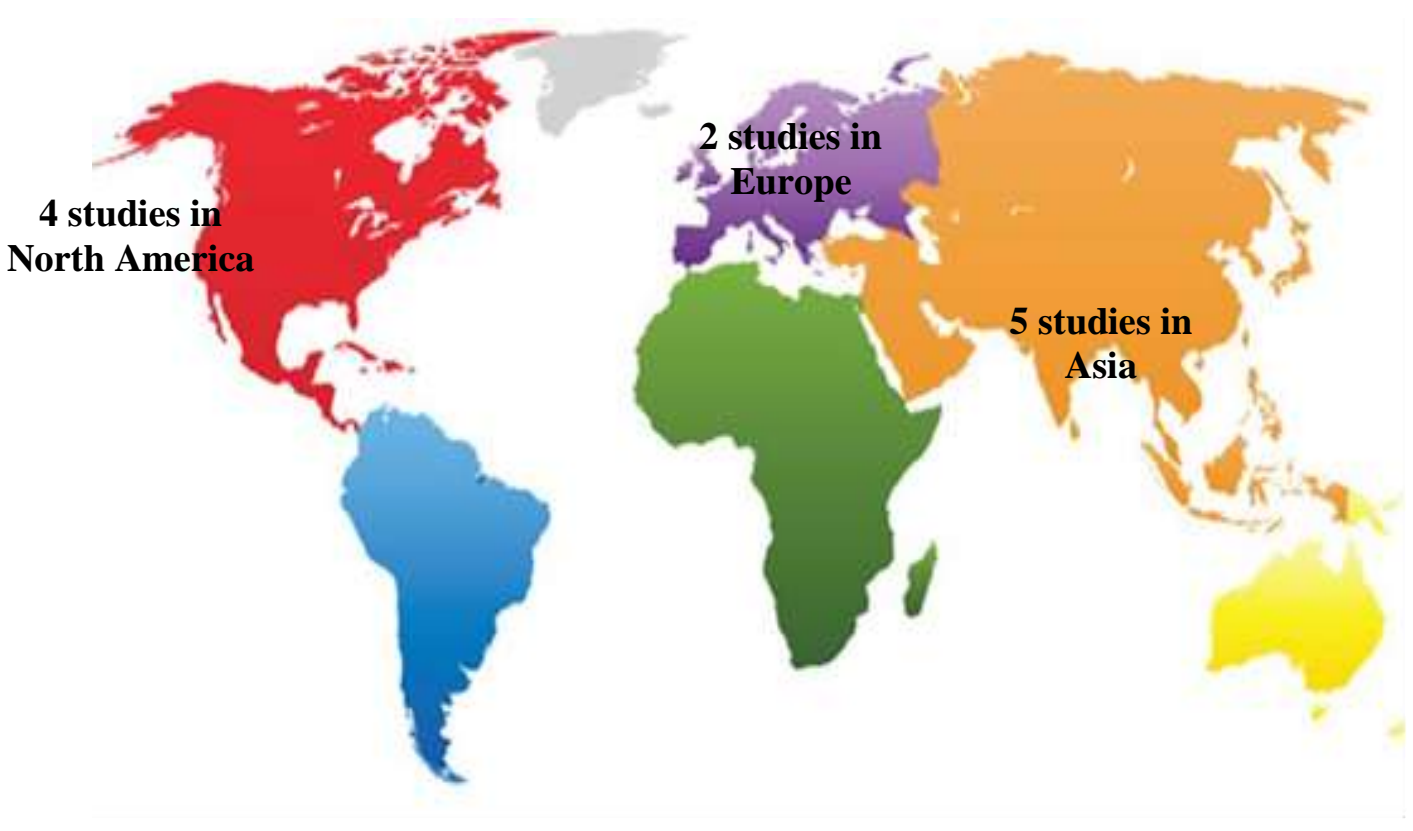

Figure 2. Map of the research area 
Table 1. Assessment of Research Quality using the Critical Appraisal Skills Program for Cohort Study

\begin{tabular}{|c|c|c|c|c|c|c|}
\hline \multirow[b]{2}{*}{ Questions of the checklist } & \multicolumn{6}{|c|}{ Publication (Author and Year) } \\
\hline & $\begin{array}{l}\text { Ratnasiri et } \\
\text { al. (2018) }\end{array}$ & $\begin{array}{l}\text { Ion et al,. } \\
(2015)\end{array}$ & $\begin{array}{l}\text { Ko et al. } \\
(2013)\end{array}$ & $\begin{array}{c}\text { Miyake } \\
\text { et al. (2013) }\end{array}$ & $\begin{array}{l}\text { Suzuki et } \\
\text { al. (2008) }\end{array}$ & $\begin{array}{c}\text { Jaddoe et al,. } \\
(2008)\end{array}$ \\
\hline Does this research address clearly focused issues? & 1 & 1 & 1 & 1 & 1 & 1 \\
\hline $\begin{array}{l}\text { Is the cohort research method appropriate for } \\
\text { answering research questions? }\end{array}$ & 1 & 1 & 1 & 1 & 1 & 1 \\
\hline $\begin{array}{l}\text { Are there enough subjects to determine that the } \\
\text { findings were not by chance? }\end{array}$ & 1 & 1 & 1 & 1 & 1 & 1 \\
\hline $\begin{array}{l}\text { Is the selection of cohorts based on objective and } \\
\text { validated criteria? }\end{array}$ & 1 & 1 & 1 & 1 & 1 & 1 \\
\hline $\begin{array}{l}\text { Is the cohort representative of the defined } \\
\text { population? }\end{array}$ & 1 & 1 & 1 & 1 & 1 & 1 \\
\hline Was there sufficient follow-up? & o & o & 1 & 1 & 1 & 1 \\
\hline Are objective and unbiased results criteria used? & 1 & 1 & 1 & 1 & 1 & 1 \\
\hline $\begin{array}{l}\text { Is the method of measuring active smoking in } \\
\text { pregnant women validated? }\end{array}$ & 1 & 1 & 1 & 1 & 1 & 1 \\
\hline Is the effect size practically relevant? & 1 & 1 & 1 & 1 & 1 & 1 \\
\hline Are there any confidence intervals given? & 1 & 1 & 1 & 1 & 1 & 1 \\
\hline $\begin{array}{l}\text { Have the confounding factors been taken into } \\
\text { account, such as the age of the pregnant woman, the } \\
\text { weight of the pregnant woman, the lifestyle (alcohol } \\
\text { consumption)? }\end{array}$ & 1 & 1 & 1 & 1 & 1 & 1 \\
\hline Can the results be applied to your research? & 1 & 1 & 1 & 1 & 1 & 1 \\
\hline Total & 11 & 11 & 12 & 12 & 12 & 12 \\
\hline
\end{tabular}

Note: Yes $=1$, No $=0$ 
Table 2. Assessment of Research Quality using the Critical Appraisal for Cross-sectional Study

\begin{tabular}{|c|c|c|c|c|c|}
\hline \multirow[b]{2}{*}{ Question of checklist } & \multicolumn{5}{|c|}{ Publication (Author and Year) } \\
\hline & $\begin{array}{l}\text { Adibelli et } \\
\text { al. (2020) }\end{array}$ & $\begin{array}{l}\text { Ju et al. } \\
\text { (2018) }\end{array}$ & $\begin{array}{l}\text { Robl et al. } \\
\text { (2012) }\end{array}$ & $\begin{array}{l}\text { Wang et al. } \\
(2020)\end{array}$ & $\begin{array}{l}\text { Kondracki } \\
\text { et al. } 2019\end{array}$ \\
\hline Does this objective clearly address the research focus / problem? & 1 & 1 & 1 & 1 & 1 \\
\hline $\begin{array}{l}\text { Is the cross-sectional research method suitable for answering } \\
\text { research questions? }\end{array}$ & 1 & 1 & 1 & 1 & 1 \\
\hline Is the method of selecting research subjects clearly written? & 1 & 1 & 1 & 1 & 1 \\
\hline Does the sampling method lead to bias (selection)? & o & $\mathrm{O}$ & o & o & o \\
\hline $\begin{array}{l}\text { Does the research sample taken represent the designated } \\
\text { population? }\end{array}$ & 1 & 1 & 1 & 1 & 1 \\
\hline Was the sample size based on pre-study considerations? & 1 & 1 & 1 & 1 & 1 \\
\hline Was a satisfactory response achieved? & 1 & 1 & 1 & 1 & 1 \\
\hline Are the research instruments valid and reliable? & 1 & 1 & 1 & 1 & 1 \\
\hline Is statistical significance assessed? & 1 & 1 & 1 & 1 & 1 \\
\hline Are confidence intervals given for the main outcome? & 1 & 1 & 1 & 1 & 1 \\
\hline $\begin{array}{l}\text { Are there any confounding factors that have not been taken into } \\
\text { account, such as the age of the pregnant woman, the weight of the } \\
\text { pregnant woman, the lifestyle (alcohol consumption)? }\end{array}$ & o & $\mathrm{o}$ & o & o & $\mathrm{O}$ \\
\hline Are the results applicable to your research? & 1 & 1 & 1 & 1 & 1 \\
\hline Total & 10 & 10 & 10 & 10 & 10 \\
\hline
\end{tabular}

Note: $Y e s=1, \mathrm{No}=\mathrm{O}$ 
Table 3. Description of the primary study meta-analysis of the effect of active smoking in pregnant women on preterm birth

\begin{tabular}{|c|c|c|c|c|c|c|c|}
\hline $\begin{array}{l}\text { Primary } \\
\text { Study }\end{array}$ & Country & Study Design & Sample & $\begin{array}{c}\mathbf{P} \\
\text { Population }\end{array}$ & $\begin{array}{c}\text { I } \\
\text { Intervention }\end{array}$ & $\begin{array}{c}\mathrm{C} \\
\text { Comparison }\end{array}$ & $\begin{array}{c}\text { O } \\
\text { Outcome }\end{array}$ \\
\hline $\begin{array}{l}\text { Ratnasiri, } \\
2018\end{array}$ & California & Cohort & 435,280 & $\begin{array}{l}\text { Pregnant } \\
\text { mother }\end{array}$ & $\begin{array}{l}\text { Active smoking during } \\
\text { pregnancy }\end{array}$ & Do not smoke & Premature Birth \\
\hline Ion, 2015 & UK & Cohort & 13,359 & $\begin{array}{l}\text { Pregnant } \\
\text { mother }\end{array}$ & $\begin{array}{l}\text { * Active and passive } \\
\text { smoking during pregnancy }\end{array}$ & Do not smoke & Premature Birth \\
\hline Ko, $\mathbf{2 0 1 3}$ & Taiwan & Cohort & 24,200 & $\begin{array}{l}\text { Pregnant } \\
\text { mother }\end{array}$ & $\begin{array}{l}\text { Active smoking during } \\
\text { pregnancy }\end{array}$ & Do not smoke & $\begin{array}{l}\text { LBW, * Premature } \\
\text { Birth, SGA }\end{array}$ \\
\hline Jaddoe, 2008 & Netherlands & Cohort & 7,098 & $\begin{array}{l}\text { Pregnant } \\
\text { mother }\end{array}$ & $\begin{array}{l}\text { * Active and passive } \\
\text { smoking during pregnancy }\end{array}$ & Do not smoke & $\begin{array}{l}\text { LBW and * } \\
\text { Premature Birth }\end{array}$ \\
\hline Suzuki, 2008 & Japan & Cohort & 1,329 & $\begin{array}{l}\text { Pregnant } \\
\text { mother }\end{array}$ & Smoking while pregnant & Do not smoke & $\begin{array}{l}\text { LBW, Premature } \\
\text { Birth, SGA }\end{array}$ \\
\hline Miyake, 2013 & Japan & Cohort & 1,565 & $\begin{array}{l}\text { Pregnant } \\
\text { mother }\end{array}$ & $\begin{array}{l}\text { * Active and passive } \\
\text { smoking }\end{array}$ & Do not smoke & $\begin{array}{l}\text { LBW, * Premature } \\
\text { Birth, SGA }\end{array}$ \\
\hline $\begin{array}{l}\text { Adibelli, } \\
2020\end{array}$ & Turkey & Cross-Sectional & 217 & $\begin{array}{l}\text { Pregnant } \\
\text { mother }\end{array}$ & $\begin{array}{l}\text { * Smoking during } \\
\text { pregnancy, Passive Smokers }\end{array}$ & Do not smoke & $\begin{array}{l}\text { LBW, * Premature } \\
\text { Birth, and other } \\
\text { Fetal Complications }\end{array}$ \\
\hline Wang, 2020 & Shanghai & Cross-Sectional & 8,586 & $\begin{array}{l}\text { Pregnant } \\
\text { mother }\end{array}$ & $\begin{array}{l}\text { * Smoking during } \\
\text { pregnancy, secondhand } \\
\text { smoke }\end{array}$ & Do not smoke & $\begin{array}{l}\text { LBW and * } \\
\text { Premature birth }\end{array}$ \\
\hline $\begin{array}{l}\text { Kondracki, } \\
2019\end{array}$ & $\begin{array}{l}\text { United } \\
\text { States of } \\
\text { America }\end{array}$ & Cross-Sectional & 130,060 & $\begin{array}{l}\text { Pregnant } \\
\text { mother }\end{array}$ & $\begin{array}{l}\text { Active smoking during } \\
\text { pregnancy }\end{array}$ & Do not smoke & * Premature Birth \\
\hline Ju, 2018 & Hawaii & Cross-Sectional & 20,061 & $\begin{array}{l}\text { Pregnant } \\
\text { mother }\end{array}$ & $\begin{array}{l}\text { Demographics of pregnant } \\
\text { women and unhealthy } \\
\text { lifestyles, * Active smoking } \\
\text { during pregnancy }\end{array}$ & $\begin{array}{l}\text { Demographics } \\
\text { of pregnant } \\
\text { women and } \\
\text { healthy lifestyles }\end{array}$ & $\begin{array}{l}\text { LBW and * } \\
\text { Premature Birth }\end{array}$ \\
\hline Robl, 2012 & Kentucky & Cross-Sectional & 270,886 & $\begin{array}{l}\text { Pregnant } \\
\text { mother }\end{array}$ & Smoking while pregnant & Do not smoke & $\begin{array}{l}\text { LBW and * } \\
\text { Premature Birth }\end{array}$ \\
\hline
\end{tabular}

* Variables entered in the meta-analysis 
Arifian et al./ The Effect of Active Smoking of Pregnant Women on Premature Birth

\section{Foest plot}

Interpretation of the results from the metaanalysis process can be seen through a forest plot. Figure 3 shows that active smoking in pregnant women increases the incidence of preterm birth. The meta-analysis of the cohort study showed that active smoking in pregnant women increased the incidence of preterm delivery by 1.34 times compared to preterm births that were not affected by active smoking in pregnant women $(\mathrm{aOR}=1.34,95 \% \mathrm{CI}=1.11-1.62, \mathrm{p}=$ o.002). The heterogeneity of the research data shows $\mathrm{I}^{2}=58 \%$ so that the distribution of the data is stated to be homogeneous (random effect model). The results of the meta-analysis of cross-sectional studies showed that active smoking in pregnant women could increase the incidence of preterm birth by 1.29 times compared to the incidence of preterm birth which was not influenced by active smoking in pregnant women $(\mathrm{aOR}=1.29,95 \% \mathrm{CI}=1.01-$ 1.63, $\mathrm{p}=0.04)$. The heterogeneity of the research data shows $\mathrm{I}^{2}=97 \%$ so that the distribution of the data is stated to be heterogeneous (random effect model).

\section{Funnel Plot}

A funnel plot is a plot that depicts the estimated effect size of each study on the estimate of its accuracy which is usually the standard error. Figure 4 shows the existence of publication bias which is indicated by the asymmetry of the plot location on the right and left sides, not forming an inverted funnel. On the right side there are 3 plots which are located far apart, on the left side there are 4 plots which are located adjacent to 2 plots that are far apart, and there are 2 plots in the middle. The plot on the right side of the graph appears to have a standard error (SE) between 0 and 0.5 . The plot on the left side of the graph has a standard error (SE) between 0 and 1. Bias also occurs from an unbalanced distance between studies on both the right and left of the funnel plot.

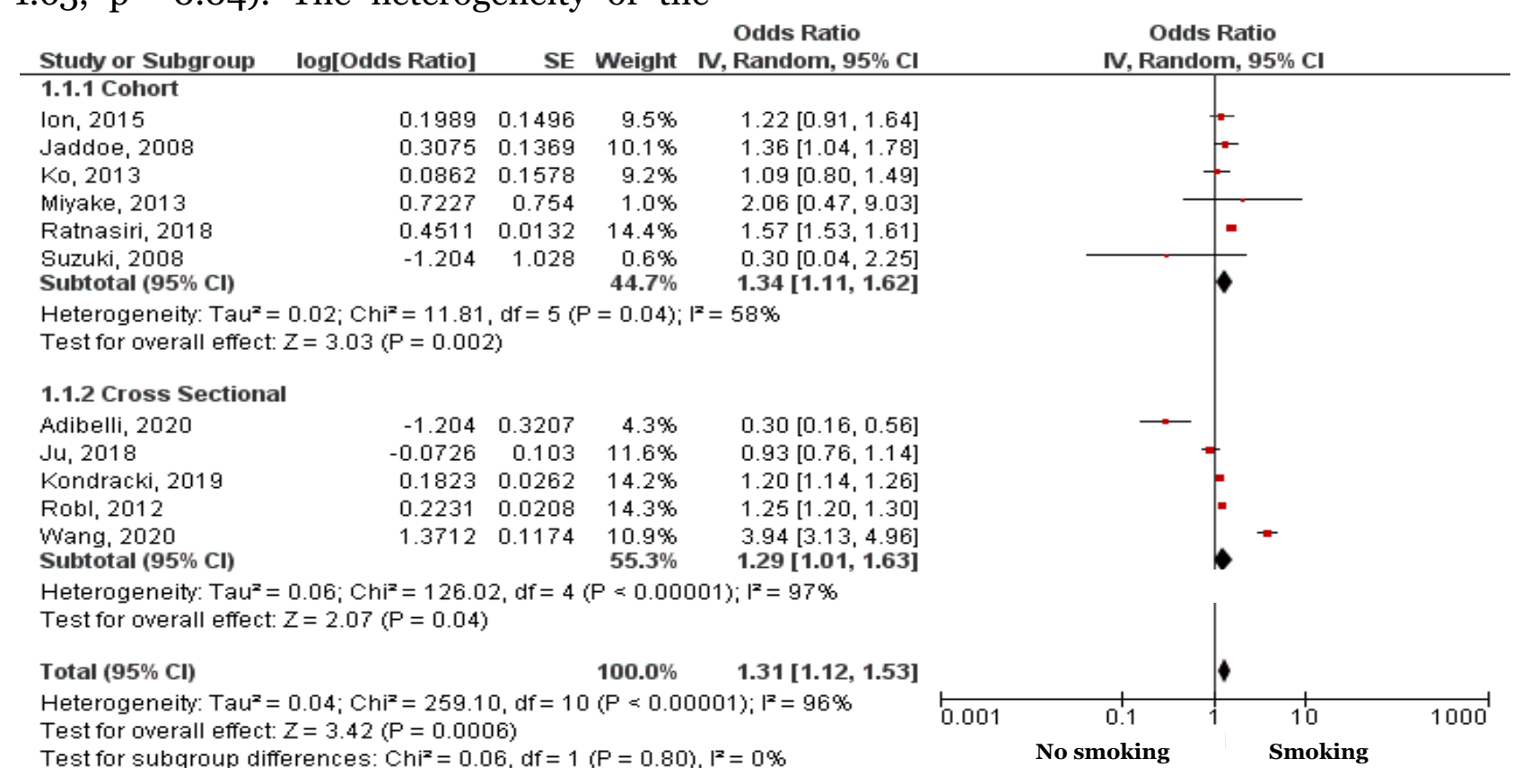

Figure 3. Forest plot of the effect of active smoking on pregnant women on preterm birth 


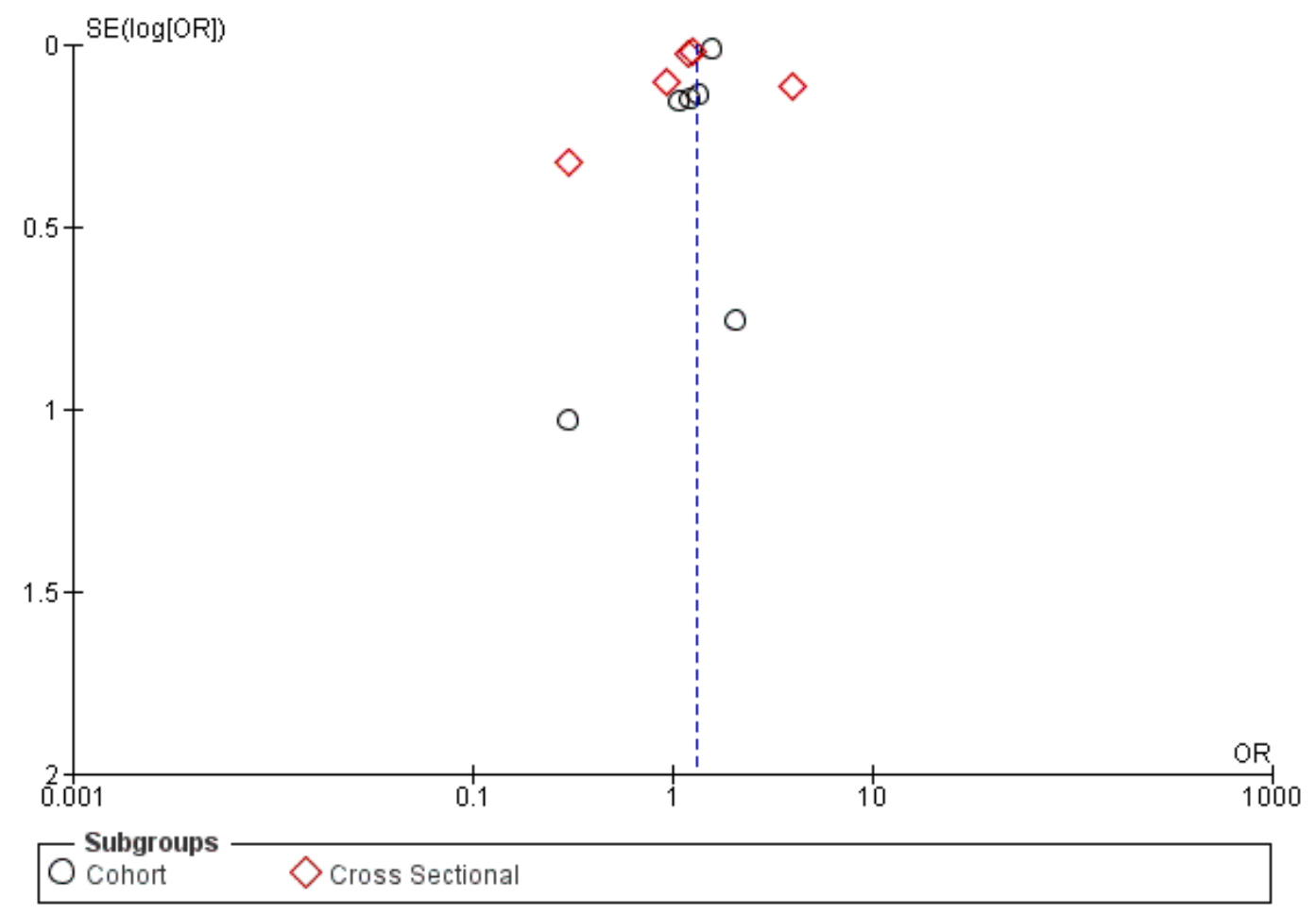

Figure 4. Funnel plot of the effect of active smoking on pregnant women on preterm birth

\section{DISCUSSION}

This systematic review and meta-analysis research raises the theme of the effect of active smoking on pregnant women on preterm labor. The independent variable which was analyzed by pregnant women was active smoking. The dependent variable in this systematic review and metaanalysis was preterm delivery. The results of the primary study carried out by systematic studies and meta-analyzes show an epidemiological study design with a larger population sample, with different demographic characteristics in different countries so as to provide a basis for concluding that active smoking has a statistical effect on the incidence of low birth weight and birth weight. premature birth.

Smoking is a well-known major risk factor for premature death from cancer, cardiovascular disease, and chronic obstructive pulmonary disease. Smoking also appears to be a major risk factor for respi- ratory tract and other systemic infections (Arcavi, 2004). When a pregnant woman smokes, she puts herself and her baby at risk. Because the fetus, the developing baby in the mother's womb (womb), comes into contact with the mother's bloodstream, any chemicals that the mother inhales or swallows can affect the fetus (Delmas, 2005). The results of the primary study analysis carried out by systematic review and meta-analysis showed that studies that met the analysis criteria were found in Africa 3 studies, Asia 6 studies, Europe 3 studies, Australia 1, North America 5 and South America 1 study.

Wagijo et al., (2017) stated that the effects of smoking on maternal health during pregnancy are physiological symptoms such as tachycardia, increased nausea and vomiting, fatigue and anorexia, as well as an increased risk of spontaneous abortion, premature rupture of membranes, preterm labor, and hypertension. According 
to Leppee et al., (2012) the impact on the fetus appears to be fetal toxicity, neurotoxicity, increased risk of Down's Syndrome, intrauterine death, fetal development retardation, low birth weight, sudden infant death syndrome, and an increased risk of congenital malformations.

This systematic and meta-analysis study used research that controlled for confounding factors which could be seen from the study inclusion requirements, namely using multivariate analysis and the statistical result reported was the adjusted odd ratio (aOR). According to Murti (2018), confounding factor is the mixing of estimates of the relationship between exposure and the disease under study, by other factors that are related, both to disease and exposure. Confounding factors influence the relationship or effect of exposure to the occurrence of disease that the study estimates (estimated) are not the same as the relationship or effect that actually occurs in the target population, or the study results are invalid (incorrect).

Estimates of the combined association of the effect of active smoking on pregnant women with preterm labor were processed using the RevMan 5.3 application with the generic inverse variance method. This method is used to analyze data in the form of: rate, time-to-event, hazard ratio, ordinal scale, adjusted estimate, difference difference of mean or ratio of mean (Anulus et al. 2019). The results of the systematic review and meta-analysis of this study are presented in the form of forest plots and funnel plots.

The forest plot is a diagram that shows visually the amount of variation (heterogeneity), CI, the average between the results of the studies examined in the meta-analysis. A funnel plot is a diagram in meta-analysis used to demonstrate possible publication bias. The funnel plot shows the relationship between the effect size of the study and the sample size of the various studies studied, which can be measured in a number of different ways (Murti, 2018)

The effect of active smoking in pregnant women on premature labor

There were 11 observational studies consisting of 6 cohort studies and 5 cross-sectional studies as a source of meta-analysis of the effect of active smoking in pregnant women on preterm labor. Analyzes were performed with subgroups of each observational study design. The meta-analysis of the cohort study showed that the effect of active smoking on pregnant women increased the risk of preterm labor by 1.34 times compared to preterm delivery that was not affected by active smoking in pregnant women $(\mathrm{aOR}=1.34,95 \% \mathrm{CI}=1.11-1.62, \mathrm{p}=$ 0.002). Meanwhile, the meta-analysis of a cross-sectional study showed that the effect of active smoking in pregnant women on preterm labor increased the risk by 1.29 times compared to preterm labor which was not influenced by active smoking in pregnant women $(\mathrm{aOR}=1.29,95 \% \mathrm{CI}=1.01$ 1.63, $\mathrm{p}=0.04$ ) .

The results of a meta-analysis conducted by Shah and Bracken, (2000) that mothers who smoked during pregnancy increased 1.27 times the incidence of preterm labor compared to nonsmokers (aOR 1.27 95\% CI 1.21-1.33). Study by Andriani et al., (2014) states that carbon monoxide causes a strong vasoconstrictor (narrowing of the blood vessels) of the placental vessels and can integrate with oxygen to form carboxyemo-globins, which can limit the amount of oxygen supplied to the fetus and cause low oxygenation of fetal tissues. .

In the study of Jaddoe et al., (2007) the effect of drinking alcohol on preterm birth showed that mothers who consumed alcohol during pregnancy increased 1.20 times the incidence of preterm labor com- 
Arifian et al./ The Effect of Active Smoking of Pregnant Women on Premature Birth

pared to mothers who did not consume alcohol (aOR 1.20, 95\% CI 0.16- 9.17). This suggests that it is necessary to control for confounding variables such as "consumption of alcoholic beverages during pregnancy" in order to determine their true effect on the target population.

\section{AUTHOR CONTRIBUTION}

Imam Setya Arifian is the main researcher who plays a role in coordinating the research, conducting all stages of the research, and completing the research paper. Vitri Widyaningsih played a role in developing ideas, research designs, and research hypotheses and Hanung Prasetya played a role in compiling the research framework, processing research data, representing the results of research analysis, and preparing research papers.

\section{CONFLICT OF INTEREST}

There is no conflict of interest in this study.

\section{FUNDING AND SPONSORSHIP}

This study is self-funded.

\section{ACKNOWLEDGEMENT}

We are very grateful to the database providers, namely PubMed, ScienceDirect, Springer Link and Google Scholar.

\section{REFERENCE}

Adibelli D, Kirca N (2020). The relationship between gestational active and passive smoking and early postpartum complications. J Matern Fetal Neonatal Med. 33(14): 2473-2479. https://doi:10.1080/14767058.2020.1763294.

Andriani H, Kuo HW (2014). Adverse effects of parental smoking during pregnancy in urban and rural areas. BMC Pregnancy Childbirth. 14(1): 115. https://doi:10.1186/s12884-0140414-y.
Anulus A, Murti B, Prasetya H (2019). Risk Factors of HIV among Male Military Personnels: A Meta Analysis. J Health Promot and Behav. 4(3): 178-188. https://doi:10.26911/thejhpb.2019.04.03.03.

Arcavi L, Benowitz NL (2004). Cigarette smoking and infection. Int Arch Intern Med. 164(20): 2206-2216. https://doi:10.1001/archinte.164.20.2206.

Arfailasufandi R, Mudigdo A, Sudiyanto A (2019). The effect of obesity, oral contraceptive and passive smoking on the risk of cervical cancer. J Epidemiol Public Health. 4(3): 189-197. https://doi:10.26911/jepublichealth.2019.04.03.06.

Azagba S, Manzione L, Shan L, King J (2020). Trends in smoking during pregnancy by socioeconomic characteristics in the United States, 20102017. BMC Pregnancy Childbirth. 20(1): 52. https://doi:10.118/s12884020-2748-y

Delmas C (2005). Smoking and pregnancy. Rev l'Infirm. 293(107): 19-li21. https://pubmed.ncbi.nlm.nih.gov/157 90002/.

Giemza M (2004). The Tobacco Box. Journal of the English Association. 53(207): 243-243. https://doi.org/10.1093/english/53.207.243a.

Guo L, Chen Y, Mi B, Dang S, Zao D, Liu R, Wang H, Yan H (2019). Ambient air pollution and adverse birth outcomes: a systematic review and meta-analysis. J Zhejiang Univ Sci B. 20(3): 238252. https://doi.org/10.1631/jzus.b1800122.

Ion RC, Wills AK, Phil D (2016). Environmental tobacco smoke exposure in pregnancy is associated with earlier delivery and reduced birth weight. Reprod Sci. 22(12): 1603-1611. https:- 
Arifian et al./ The Effect of Active Smoking of Pregnant Women on Premature Birth

//doi:10.1177/1933719115612135.

Jaddoe VWV, Bakker R, Hofman A, Mackenbach JP, Moll HA, Steegers EAP, Witteman JCM (2007). Moderate alcohol consumption during pregnancy and the risk of low birth weight and preterm birth. the generation $\mathrm{R}$ study. Ann Epidemiol. 17(10): 834840. https://doi: 10.1016/j.annepidem.2007.04.001.

Jaddoe VWV, Troe EJWM, Hofman A, Mackenbach JP, Moll HA, Steegers EAP, Witteman JCM (2008). Active and passive maternal smoking during pregnancy and the risks of low birthweight and preterm birth: the Generation R Study. Paediatr Perinat Epidemiol. 22(2): 162-171. https://doi:10.1111/j.1365-3016.2007.00916.x.

Ju A, Heyman MB, Garber AK, Wojcicki JM (2018). Maternal obesity and risk of preterm birth and low birthweight in Hawaii PRAMS, 2000-2011. Matern Child Health J. 22(6): 893-902. https://doi:893-902. 893-902

Ko T, Tsai LY, Chu LC, Yeh SJ, Leung C, Chen CY, Chou HC, et al. (2013). Parental smoking during pregnancy and its association with low birth weight, small for gestational age, and preterm birth offspring: A birth cohort study. Pediatr Neonatol. 55(1): 20-27. https://doi.org/10.1016/j.pedneo.2013.05.005.

Kondracki AJ, Hofferth SL (2019). A gestational vulnerability window for smoking exposure and the increased risk of preterm birth: how timing and intensity of maternal smoking matter. Reprod Health. 16(43): 1-10. https://doi.org/10.1186/s12978-019-0705-x Leppée M, Culig J, Eric M (2012). Cigarette smoking during pregnancy in two regions: Cross-sectional study. Asian
Pac J Reprod. 1(3): 212-216. https://doi:10.1016/S2305-0500(13)60079-2

Listiani FRM, Salimo H, Murti B (2018). Path analysis on the biological and social economic determinants of neonatal death in Bantul District, Yogyakarta. J Matern Child Health. 03(02): 91-99. https://doi.org/10.26911/thejmch.2018.03.02.01.

Miyake Y, Tanaka K, Arakawa M (2013). Active and passive maternal smoking during pregnancy and birth outcomes: the Kyushu Okinawa maternal and child health study. BMC Pregnancy Childbirth. 13(1): 157. http://www.biomedcentral.com/1471-2393/13/157

Murti B (2018). Prinsip dan Metode Riset Epidemiologi. $5^{\text {th }}$ edn. Surakarta: Universitas Sebelas Maret.

Ratnasiri AWG, Parry SS, Arief VN, DeLacy IH, Lakshminrusimha S, Halliday LA, DiLibero RJ, Basford KE (2018). Temporal trends, patterns, and predictors of preterm birth in California from 2007 to 2016, based on the obstetric estimate of gestational age. Matern Health Neonatol Perinatol. 4(1): 25. https://doi.org/10.1186/s40748-018-0094-0.

Robl JM (2012). The impact of maternal smoking in kentucky and effect of the giving infants and families tobaccofree starts pilot project on smoking cessation and birth outcomes. University of Kentucky. https://uknowledge.uky.edu/cgi/viewcontent.cgi?art icle $=1003 \&$ context $=$ khp_etds.

Shah NR, Bracken MB (2000). A systematic review and meta-analysis of prospective studies on the association between maternal cigarette smoking and preterm delivery. Am J Obstet Gynecol. 182(2): 465-472. https://doi.org/10.1016/s0002-9378(oo)70240-7. 
Arifian et al./ The Effect of Active Smoking of Pregnant Women on Premature Birth

Sudaryanto, Rahardjo SS, Indarto D (2019). Risk factors of hypertension among women in Sragen, Central Java. J epidemiol public health. 4(2): 127137. https://doi.org/10.26911/jepublichealth.2019.04.02.08.

Susanti I, Salimo H, Dewi YLR (2020). Effects of maternal socioeconomic, psychological, nutritional factor, and ambient smoke exposure, on the risk of low birth weight: A multilevel evidence from Gunungkidul, Yogyakarta. 05(04): 446-455. https://doi.org/10.26911/thejmch.2020.05.04.12.

Suzuki K, Tanaka T, Kondo N, Minai J, Sato M, Yamagata Z (2008). Is maternal smoking during early pregnancy a risk factor for all low birth weight infants?. J Epidemiol. 18(3): 89-96. https://doi.org/10.2188/jea.je2007415.

UNICEF (2017). Levels and Trends in Child Mortality: Report 2017. United Nations Inter-Group for Child Mortality
Estimation.

Wagijo M, Sheikh A, Duijts L, Been JV (2017). Reducing tobacco smoking and smoke exposure to prevent preterm birth and its complications. Paediatr Respir Rev. 22(1): 3-10. https://doi.org/10.1016/j.prrv.2015.09.002 Wang R, Sun T, Yang Q, Yang Q, Wang J, Li H, Tang Y, Yang L, Sun J (2020). Low birthweight of children is positively associated with mother's prenatal tobacco smoke exposure in Shanghai: a cross- sectional study. BMC Pregnancy Childbirth, 20(1): 603. https://doi.org/10.1186/s12884020-03307-x.

WHO (2018). Heart disease and stroke are the commonest ways by which tobacco kills people. WHO. 1(1): 1-2. Available at:http://www.searo.who.int/tobacco/data/ino_rtc_reports,.

WHO (2019). 2019 Health SDG Profile: Indonesia. 2-5. 